\title{
DIPTERA FROM NEPAL
}

\section{HELEOMYZIDAE}

\author{
By J. C. DEEMING \\ SYNOPSIS
}

One species of Heleomyzidae was taken on J. Tyson's Expedition to West Nepal in I953. This species, Suillia nigripes Czerny, hitherto little known and recorded only from China, is here redescribed and recorded from Sikkim and Nepal. No Heleomyzidae were taken during the British Museum Expedition to East Nepal in I96I-62. A new species from Darjeeling is described here for convenience and related species are discussed.

\section{Suillia nigripes Czerny}

(Text-figs. I-4)

Suillia nigripes Czerny, I932: 28.

THIS species was described from a single $\sigma^{*}$ in poor condition collected at Sze-Tschuan, Ta-tsein-lu, China, at the extreme eastern margin of the Himalayas. As Czerny's type was in such poor condition as to render a complete description impossible, the species is redescribed from both sexes from material in the British Museum (Natural History) from Nepal and Sikkim. This is the only species of Suillia R.-D. known to me that has spurs on both fore and hind basitarsi in the male.

§. A rusty brown, heavily dusted species, with hyaline wings clouded on cross-veins, legs and antennae more or less infuscated, and abdomen predominantly black.

Head (Text-fig. I) rather square ; frons broader than an eye ; parallel sided, anteriorly yellowish, and densely haired; face and jowls yellowish, intensively golden yellow dusted ; jowls two-thirds as wide as the obliquely oval eye is high ; orbital plates, ocellar triangle and occiput thickly brownish grey dusted; antennae fuscous, except ventrally at the base of the third segment; arista practically bare ; clypeus prominent; palpus somewhat infuscated ; all head bristles strong.

Thorax brownish grey dusted, with a blackish line extending from anterior margin to base of scutellum ; no dark spots at bases of dorsocentral bristles ; humerus darker, especially below ; the anterior of the two notopleurals the longer; one sternopleural; scutellum, devoid of setulae, rather pointed, lacking an apical tooth, paler medially, the apical bristles closer to one another than to the laterals; halteres yellow, apically fuscous.

Legs rusty yellow, more or less infuscated, especially centrally on femora ; all femora ventrally with dense, long, fine hairs ; fore femur with a row of 8-1o long posterodorsal bristles ; mid femur less swollen than the fore or hind, with a row of 8 anterodorsal bristles, of which only the apical three are long, three long anteroventral bristles on the apical third and two long posteroventral bristles preapically; hind femur with a row of 7-8 strong anterodorsal bristles, a row of 4 bristles close above this on the apical half and a row of three such bristles slightly below it; fore tibia with long, fine, erect hairs on ventral and posterior surfaces, the preapical dorsal bristle long; mid tibia similarly haired, with two strong preapical dorsal bristles, of which the

Bull. Brit. Mus. (nat. Hist.), Ent. 17 (го) 1966. 
anterior is more apical, three strong apical bristles, of which the central is the longest, and several short spurs interspersed between these bristles; hind tibia with fine, rather long hairs on all surfaces, but this not nearly as outstanding as on the other tibiae, the preapical dorsal bristle long ; fore basitarsus (fig. 3) with long erect hairs on posterior surface, and an almost straight, black apical ventral spur; mid basitarsus similarly haired but lacking an apical spur; hind basitarsus (Text-fig. 4) short haired, with a short, black, recurved apical ventral spur; the apical segments of all tarsi fuscous.

Wing (Text-fig. 2) yellowish hyaline with small dark clouds on the cross-veins.

Abdomen black, greyish dusted, with long bristles at sides of tergites only ; sternites densely long haired ; tergites 6 and 7 yellow; hypopygium and anal cerci long haired.

Length $6.5 \mathrm{~mm}$.

ㅇ. Resembling $\hat{\sigma}$, lacking the long hairs on femora and tibiae ; having only one preapical dorsal bristle on mid tibia; no spurs on basitarsi ; the sternites short haired ; 7 th abdominal segment slightly compressed laterally, dusted, not longer than the fifth.

Sikkim, Gnatang, I2,000 ft, 3I.iii.I924, I ๙ (R. W. G. Hingston). W. NEPAL : Baitadi, Tinkar Khola, I3,000 ft, 3.vii.I953, I 우 (J.B. Tyson). Both specimens are in the British Museum (Natural History).
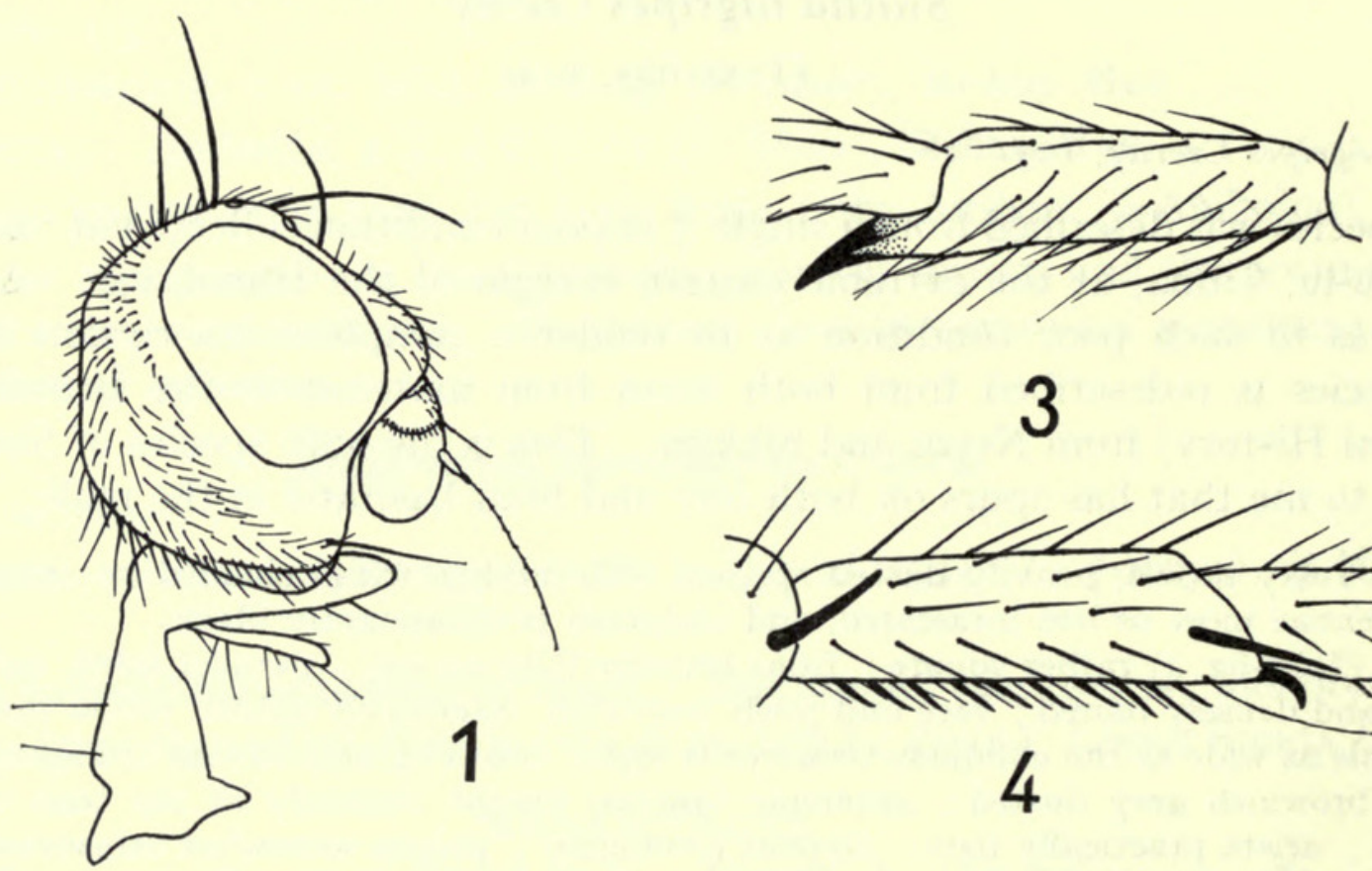

3
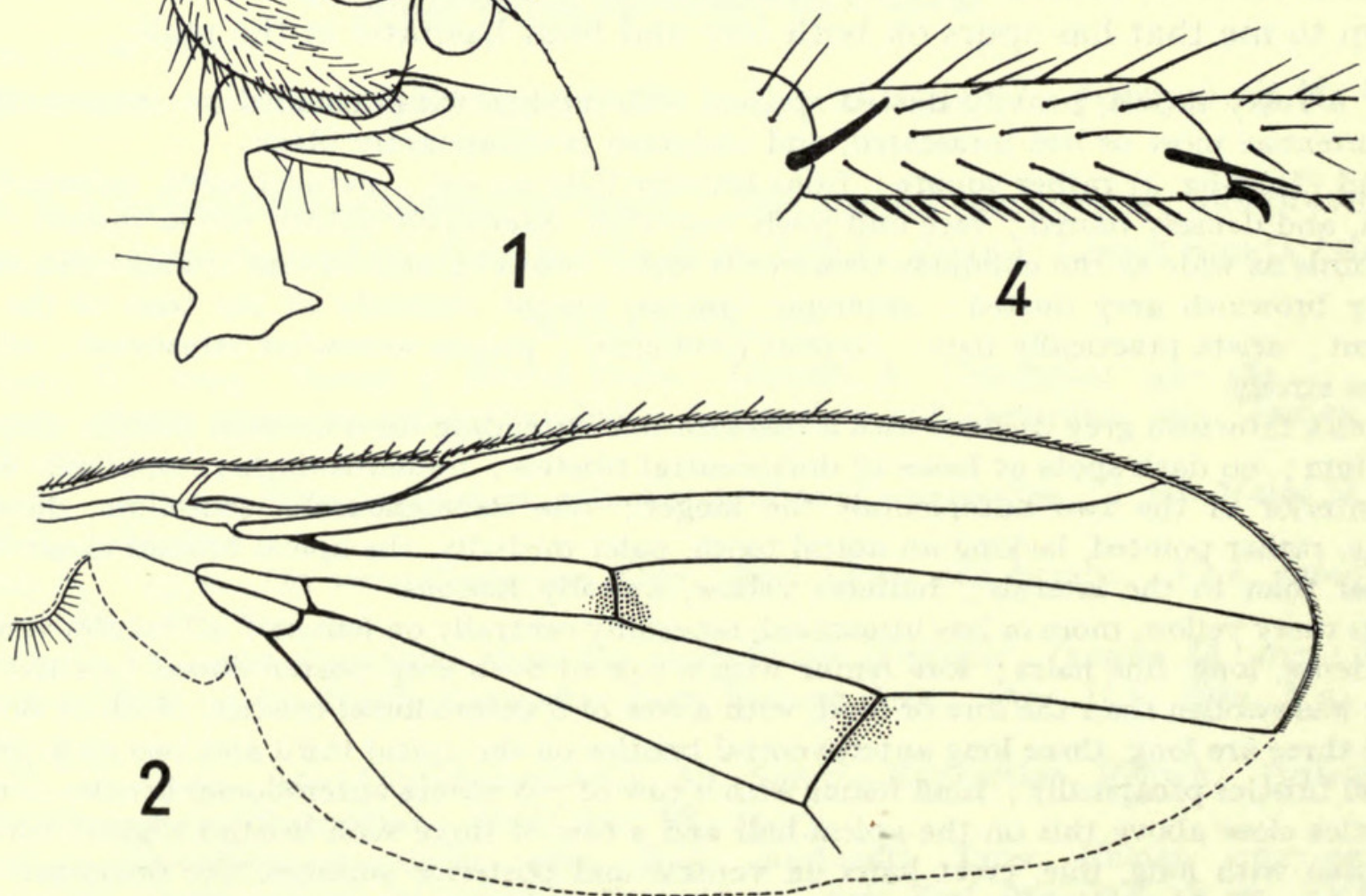

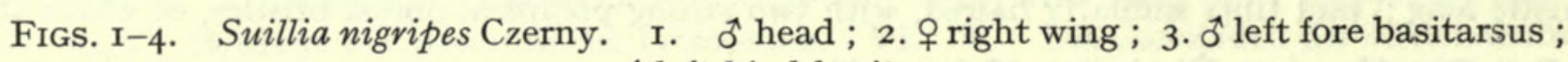
4. 0 left hind basitarsus. 


\section{Suillia himalayensis sp. $\mathrm{n}$.}

A reddish brown species closely resembling S. stroblii Czerny, but differing from it in having slightly longer aristal plumosity, the face fuscous, the cerebral hairs brown, the abdomen predominantly black, and in the male by having dense, long sinuate hairs on the sternites.

đ. Head higher than long; facial keel strong; antennae unicolorous with head, aristal plumosity slightly longer than depth of third antennal segment; frons narrowly darkened anteriorly; face and jowls anteriorly noticeably blackened, thinly white dusted; cerebral bristles brown.

Thorax reddish brown, heavily dusted, paler on the pleurae, infuscated only on lower margin of humerus and narrowly to base of wing; mesopleuron bare; scutellum rounded apically, devoid of setulae; halteres apically fuscous.

Legs yellow ; mid-coxa with numerous short black blunt spines interspersed among the long bristles ventrally; fore femur with a row of 8-1o long anterodorsal bristles along its whole length, ventrally with long fine erect hair ; mid femur with two long and some weaker bristles anteriorly on the apical half ; ventrally with shorter, apically stronger hairs ; hind femur with a curving row of 8 long anterodorsal bristles and a pair of bristles below this row, and long erect ventral hairs ; all tibiae with dense decumbent ventral hairing, which is longest on the mid tibia ; each tibia with one preapical dorsal bristle ; mid tibia apically with one long ventral bristle, a short bristle on either side and some short spines interspersed between ; fore basitarsus longer than the remainder of the tarsus, apically weakly produced into a blunt ventral projection ; mid basitarsus with long posteroventral hairs; tarsi very slightly infuscated apically.

Wings yellowish hyaline, veins brown, as in S. stroblii Cz.; a strong well defined brown spot at apex of second vein; apices of third and fourth veins and posterior cross-vein clouded. Costa between mouths of 3 rd and 5 th veins pale yellowish white.

Abdomen black, dirty yellow on bases of first to third tergites, and on two lateral spots on fourth to sixth tergites; third tergite with strong apical bristles laterally; fourth to sixth tergites strongly bristled across their whole width; sternites with long dense sinuous hairs; genitalia very similar to that of $S$. stroblii $\mathrm{Cz}$., paralobes semitriangular with dense long hair.

Length $7.5 \mathrm{~mm}$.

ㅇ. Resembling $\mathrm{o}^{\mathrm{t}}$, lacking long hairing on legs and abdomen, the fore basitarsal projection and the short spines on the mid coxa ; fore femur with a row of weak posteroventral bristles; ovipositor slightly laterally compressed, as long as the previous segment, both these segments dirty yellow.

Holotype ô, paratypes 4 ๙ै, 5 ㅇ, India: Darjeeling, ix.I9I3 (E. Brunetti). Same data, I5.vi-I5 . vii. I9I6, 2 ô, ㅇ․ Same data, I3-I8.ix.I9I3, ㅇ. (Two of the paratypes without heads). Types deposited in British Museum (Natural History).

There are two other species from "India" that closely resemble S. stroblii and $S$. himalayensis, but these are not described here due to lack of precise data accompanying the specimens. Whereas both S. stroblii and himalayensis have short blunt spines on the mid-coxa in the $\hat{\sigma}$, these species have not.

S. stroblii is known from Styria, Budapest and the Ussuri region of Eastern Russia. Specimens used for comparison were collected from lush herbage bordering a coniferous forest at Seis am Schlern, Western Dolomites during June I964.

Gorodkov (I962) described (in Russian) five new species of Suillia R.-D. from Southern Russia. None of these species has the jowls as wide as S. nigripes Cz., or genital forceps of the same shape as S. himalayensis. 


\section{REFERENCES}

Czerny, L. I932. Palaearktische Helomyziden des Zoologischen Instituts des Akademie der Wissenschaft d. U.d.S.S.R. (Diptera). Trudy. zool. Inst. Leningr., 1 : 25-33.

- 1935. Ergänzungen zu meiner Monographie der Helomyziden. IX. A. Palaearktische Region. Konowia $14: 27 \mathrm{I}-287$.

Gorodkov, K. B. I962. The new Palearctic species of the family Helomyzidae (Diptera) [In Russian]. Trudy. zool. Inst. Leningr., 30 : 310-325, 33 figs. 


\section{$2 \mathrm{BHL}$ Biodiversity Heritage Library}

Deeming, J C. 1966. "Heleomyzidae. Diptera from Nepal." Bulletin of the British Museum (Natural History) Entomology 17, 435-438.

https://doi.org/10.5962/bhl.part.14818.

View This Item Online: $\underline{\text { https://www.biodiversitylibrary.org/item/19366 }}$

DOI: https://doi.org/10.5962/bhl.part.14818

Permalink: https://www.biodiversitylibrary.org/partpdf/14818

\section{Holding Institution}

Natural History Museum Library, London

\section{Sponsored by}

Natural History Museum Library, London

\section{Copyright \& Reuse}

Copyright Status: In copyright. Digitized with the permission of the rights holder.

Rights Holder: The Trustees of the Natural History Museum, London

License: http://creativecommons.org/licenses/by-nc-sa/4.0/

Rights: http://biodiversitylibrary.org/permissions

This document was created from content at the Biodiversity Heritage Library, the world's largest open access digital library for biodiversity literature and archives. Visit BHL at https://www.biodiversitylibrary.org. 